\title{
Actinomadura sputi sp. nov., isolated from the sputum of a patient with pulmonary infection
}

\author{
Correspondence \\ A. F. Yassin \\ yassin@mibi03.meb.uni-bonn.de
}

\author{
A. F. Yassin, ${ }^{1}$ C. Spröer, ${ }^{2}$ C. Siering ${ }^{3}$ and H.-P. Klenk ${ }^{2}$ \\ ${ }^{1}$ Institut für Medizinische Mikrobiologie und Immunologie der Universität Bonn, 53127 Bonn,
Germany \\ ${ }^{2} \mathrm{DSMZ}$ - Deutsche Sammlung von Mikroorganismen und Zellkulturen GmbH, Inhoffenstrasse 7b, \\ D-38124 Braunschweig, Germany \\ ${ }^{3}$ Kekulé-Institut für Organische Chemie und Biochemie der Universität Bonn, 53121 Bonn, \\ Germany
}

\begin{abstract}
The taxonomic position of an actinomycete, strain IMMIB L- $889^{\top}$, isolated from the sputum of a 64-year-old man, was determined using a polyphasic taxonomic approach. The strain had chemical and morphological properties that were consistent with its classification in the genus Actinomadura. It formed a distinct phyletic line in the 16S rRNA gene tree of Actinomadura and was most closely related to the type strain of Actinomadura hallensis ( $98.4 \%$ sequence similarity), but could be readily distinguished from the latter species using DNA-DNA relatedness and phenotypic data. The combined genotypic and phenotypic data indicate that strain IMMIB $\mathrm{L}-889^{\top}$ represents a novel species of the genus Actinomadura, for which the name Actinomadura sputi sp. nov. is proposed. The type strain is IMMIB L-889 $\left(=\mathrm{DSM} 45233^{\top}=\mathrm{CCUG}^{\top} 6587^{\top}\right)$.
\end{abstract}

The genus Actinomadura Lechevalier and Lechevalier 1968 (Lechevalier \& Lechevalier, 1968) belongs to the family Thermomonosporaceae (Stackebrandt et al., 1997; Zhang et al., 1998, 2001). This taxon also includes the genera Actinocorallia (Inuma et al., 1994), Spirillospora (Couch, 1963) and Thermomonospora (Henssen, 1957). At the time of writing, the genus Actinomadura encompassed 40 species with validly published names (www.bacterio.cict.fr) that can be delineated using a combination of genotypic and phenotypic data (Kroppenstedt \& Goodfellow, 1991; Lu et al., 2003; Zhang et al., 2001). The primary reservoir of actinomadurae is soil (Chormonova \& Preobrazhenskaya, 1981; Quintana et al., 2003; Lu et al., 2003; Ara et al., 2008), although members of the genus are better known as causal agents of actinomycetoma (McNeil \& Brown, 1994; Trujillo \& Goodfellow, 1997, 2003), superficial or deep suppurating tumefactions of the skin and subcutaneous tissues that result from soil contamination of a penetrating wound. Actinomadura should also be considered as causative agents for non-mycetomic infections such as pneumonia. Actinomadura madurae accounted for $11.5 \%$ of the aerobic actinomycetes from clinical specimens that were referred to the Actinomycete Laboratory of the Centers for Disease Control and Prevention (CDC, USA) during the period October 1985 to February 1988 and is suggested to play some role in pneumonitis or bronchitis (McNeil et al., 1990). A. madurae was isolated originally

The GenBank/EMBL/DDBJ accession number for the 16S rRNA gene sequence of strain IMMIB L-889 ${ }^{\top}$ is FM957483. from a 46-year-old alcoholic man with pneumonia suspected of Tbc reactivation (Bär et al., 2003). The majority of clinical isolates from sputa or bronchoalveolar lavage fluid in Japan are A. madurae (Hanafy et al., 2006). In the present study, the isolation and identification of an actinomycete from the sputum of a 64-year-old man suspected to be infected with Mycobacterium tuberculosis are reported.

For isolation, sputum of a 64-year-old man was treated using a $\mathrm{NaOH}-\mathrm{N}$-acetyl cysteine decontamination procedure (Master, 1994). After decontamination, the sample was centrifuged at 3000 r.p.m. for $20 \mathrm{~min}$. The supernatant was discarded and the sediment was inoculated into a Mycobacteria Growth Indicator tube (MGIT; Becton Dickinson) and on Löwenstein-Jensen medium. The organism, designated strain IMMIB L- $889^{\mathrm{T}}$, was recovered on Löwenstein-Jensen and was subsequently cultivated on brain heart infusion (BHI) agar, glucose-yeast extract-malt extract agar (GYM; medium 65 DSMZ Catalogue) and Columbia agar supplemented with $5 \%$ sheep blood. Gram and Ziehl-Neelsen stains were applied to mycelia grown on Columbia agar. To determine the morphological characteristics of the isolate, it was grown on yeast extract $/ \mathrm{malt}$ extract agar (ISP medium 2), oatmeal agar (ISP medium 3) and inorganic salts/starch agar (ISP medium 4) as described by Shirling \& Gottlieb (1966) and was examined for pigmentation and colour of aerial and substrate mycelia. Growth temperatures were determined by incubating the organism at 27,37 and $42{ }^{\circ} \mathrm{C}$ on Columbia agar. 
Strain IMMIB L-889 ${ }^{\mathrm{T}}$ was examined for a range of phenotypic characteristics using standard procedures (Gordon, 1966, 1967; Gordon \& Mihm, 1957; Yassin et al., 1995). Biomass for chemotaxonomic studies was derived from a 7-day-old BHI broth shake culture incubated at $37^{\circ} \mathrm{C}$, harvested by centrifugation and washed with distilled water. Standard procedures were used to determine the isomeric form of the diaminopimelic acid (Becker et al., 1964), whole-cell sugars (Lechevalier, 1968), non-hydroxylated fatty acids (Minnikin et al.,1980; Yassin et al., 2007), polar lipids (Yassin et al., 1993) and isoprenoid quinones (Collins et al., 1977; Yassin \& Hupfer, 2006).

Genomic DNA extraction and PCR-mediated amplification of the 16S rRNA gene were carried out using established procedures (Rainey et al., 1996). The purified PCR products were sequenced using a Taq DyeDeoxy Terminator Cycle Sequencing kit (Applied Biosystems) as described by the manufacturer. A Genetic Analyzer (310; Applied Biosystems) was used for electrophoresis of the sequence reaction products. The $16 \mathrm{~S}$ rRNA gene sequence of strain IMMIB L- $889^{\mathrm{T}}$, as well as those of species of the genus Actinomadura with validly published names (retrieved from GenBank), were added to the ARB database (Ludwig et al., 2004) and aligned using the respective tool from the ARB package. The resulting alignment was corrected manually and evolutionary trees were inferred using maximumparsimony (Fitch, 1971), neighbour-joining (Saitou \& Nei, 1987) and maximum-likelihood (Felsenstein, 1981) methods. The evolutionary distance matrix for the neighbourjoining method was calculated using the correction of Jukes \& Cantor (1969). Topologies of the neighbour-joining tree were evaluated using bootstrap analyses (Felsenstein, 1985) based on 500 resamplings. DNA-DNA relatedness studies were performed between strain IMMIB $\mathrm{L}-889^{\mathrm{T}}$ and Actinomadura hallensis DSM $45043^{\mathrm{T}}$. DNA was isolated using a French pressure cell (Thermo Spectronic) and was purified by chromatography on hydroxyapatite as described by Cashion et al. (1977). DNA-DNA hybridization was carried out as described by De Ley et al. (1970) under consideration of the modifications described by Huß et al. (1983) using a model Cary 100 Bio UV/VIS-spectrophotometer equipped with a Peltier-thermostatted $6 \times 6$ multicell changer and a temperature controller with in situ temperature probe (Varian).

To establish the phylogenetic position of strain IMMIB L$889^{\mathrm{T}}$, its $16 \mathrm{~S}$ rRNA gene sequence was determined in this study (1509 nt). Sequence database searches revealed that strain IMMIB L- $889^{\mathrm{T}}$ was most closely related to species of the genus Actinomadura (data not shown). Phylogenetic analysis confirmed the placement of strain IMMIB L- $889^{\mathrm{T}}$ within the genus Actinomadura. A tree constructed using the neighbour-joining method showing the nearest phylogenetic relatives of strain IMMIB L-889 $9^{\mathrm{T}}$ is shown in Fig. 1. It is evident from the tree that strain IMMIB L- $889^{T}$ is most closely related to the type strain of $A$. hallensis. The association of strain IMMIB L- $889^{\mathrm{T}}$ with A. hallensis was supported by all of the treeing algorithms and by a bootstrap value of $100 \%$. Comparative $16 \mathrm{~S}$ rRNA gene sequence analysis demonstrated that strain IMMIB L- $889^{\mathrm{T}}$ displayed sequence similarity values of less than $98.4 \%$ to the type strains of recognized members of the genus Actinomadura. Highest sequence similarity was shown to A. hallensis DSM $45043^{\mathrm{T}}(98.4 \%)$. DNA-DNA relatedness studies between strain IMMIB L-889 $9^{\mathrm{T}}$ and A. hallensis DSM $45043^{\mathrm{T}}$ clearly demonstrated that both of them belong to separate genomic species. The mean DNA-DNA relatedness value was $61.3 \pm 2.96 \%$, a value well below the $70 \%$ cut-off point recommended for the assignment of strains to the same genomic species (Wayne et al., 1987). It is also apparent that strain IMMIB L- $889^{\mathrm{T}}$ can be distinguished from A. hallensis using a combination of phenotypic properties (Table 1).

Strain IMMIB L-889 ${ }^{\mathrm{T}}$ also exhibited typical chemical markers of members of the genus Actinomadura. The cell wall of strain IMMIB L- $889^{\mathrm{T}}$ was of type III (Lechevalier \& Lechevalier, 1970), contained meso-diaminopimelic acid as the wall diamino acid and type B whole-cell sugars (madurose was the diagnostic sugar). The predominant menaquinone was a hexahydrogenated menaquinone with nine isoprene units, MK-9 $\left(\mathrm{H}_{6}\right)$. In addition, small amounts of MK-9 $\left(\mathrm{H}_{8}\right)$ and MK-9 $\left(\mathrm{H}_{4}\right)$ were also detected. The phospholipid pattern was type PI sensu Lechevalier et al. (1977) and consisted of diphosphatidylglycerol, phosphatidylglycerol, phosphatidylinositol and phosphatidylinositol mannoside. The fatty acid profile consisted of complex mixtures of fatty acids, notably $\mathrm{C}_{14: 0}(0.9 \%$ of total fatty acids), $\mathrm{C}_{15: 0}(0.7 \%)$, iso- $\mathrm{C}_{16: 0}(9.4 \%), \mathrm{C}_{16: 1} \omega 7 c(0.6 \%)$, $\mathrm{C}_{16: 0}(34.3 \%)$, anteiso- $\mathrm{C}_{17: 0}(0.6 \%), \mathrm{C}_{17: 1} \omega 8 c(1.0 \%)$, $\mathrm{C}_{17: 0}(3.2 \%), 10$-methyl- $\mathrm{C}_{17: 0}(0.8 \%)$, iso- $\mathrm{C}_{18: 0}(1.9 \%)$, $\mathrm{C}_{18: 1} \omega 9 c(18.0 \%), \mathrm{C}_{18: 1} \omega 7 c(0.6 \%), \mathrm{C}_{18: 0}(9.0 \%), 10-$ methyl- $\mathrm{C}_{18: 0}(14.5 \%), \mathrm{C}_{20: 1}(0.6 \%), \mathrm{C}_{20: 0}(0.4 \%), \mathrm{C}_{24: 1}$ $(0.7 \%)$ and $\mathrm{C}_{24: 0}(0.4 \%)$.

The phenotypic properties of strain IMMIB L- $889^{\mathrm{T}}$ were also consistent with its classification in the genus Actinomadura. The isolate was an aerobic, non-motile, Gram-positive, non-acid-alcohol-fast actinomycete that formed extensively branched, non-fragmenting substrate mycelia which bore abundant aerial mycelia. The substrate mycelia appeared grey on Columbia blood agar, yellowish on ISP medium 2, and whitish in colour on ISP medium 3, ISP medium 4 and GYM agar. The aerial mycelia of strain IMMIB L-889 ${ }^{\mathrm{T}}$ appeared grey in colour on Columbia blood agar, creamy on ISP medium 2, skin-coloured on both ISP medium 3 and GYM agar, and white on ISP medium 4 . The aerial mycelia bore straight chains of two to four spores at the tips of sporulating aerial hyphae. The spores were elongated and had smooth surfaces. Diffusible pigments were not produced. Melanoid pigments were not produced on ISP medium 6 or ISP medium 7. The organism grew at $27-37{ }^{\circ} \mathrm{C}$, but not at $42{ }^{\circ} \mathrm{C}$. Strain IMMIB L- $889^{\mathrm{T}}$ was examined for a range of phenotypic properties, the results of which are listed in Table 1 and cited in detail in the species description. 


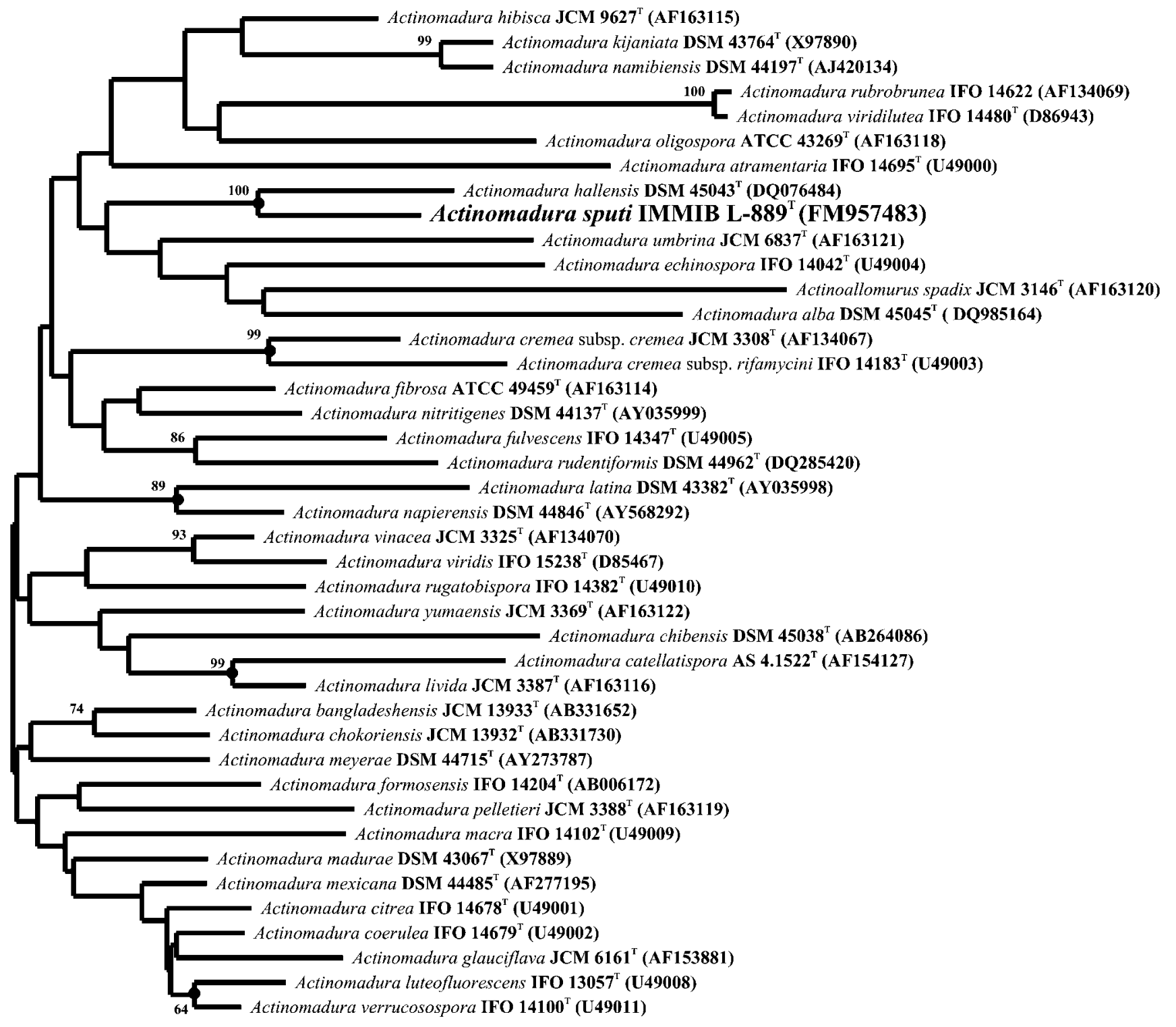

$5.0 \%$

Fig. 1. Neighbour-joining tree showing the position of isolate IMMIB L-889 ${ }^{\top}$ in the genus Actinomadura. Numbers at the nodes indicate the level of bootstrap support (\%) based on neighbour-joining analyses of 500 resampled datasets; solid circles indicate that the corresponding nodes (groupings) were also recovered in maximum-likelihood and maximum-parsimony trees. Bar, $5.0 \%$ sequence divergence.

On the basis of the genotypic and phenotypic data, strain IMMIB L- $889^{\mathrm{T}}$ is a member of the genus Actinomadura and represents a novel species, for which the name Actinomadura sputi sp. nov. is proposed.

\section{Description of Actinomadura sputi sp. nov.}

Actinomadura sputi sp. nov. (spu'ti. L. gen. n. sputi of sputum).
Aerobic, Gram-positive, non-acid-alcohol-fast, non-motile actinomycete. Forms non-fragmenting, whitish (on ISP medium 3, ISP medium 4 and GYM agar), yellowish (on ISP medium 2) or grey (on Columbia blood agar) substrate mycelia that bear white (on ISP medium 4), creamy (on ISP medium 2), skin-coloured (on ISP medium 3 and GYM agar) or grey (on Columbia blood agar) aerial mycelia. Aerial mycelia bear straight chains of two to four rod-shaped spores with smooth surfaces. Grows at 
Table 1. Differential phenotypic characteristics of strain IMMIB L-889 ${ }^{\top}$ and A. hallensis DSM $45043^{\top}$

Strains: 1, IMMIB L- $889^{\mathrm{T}}$; 2, A. hallensis DSM $45043^{\mathrm{T}}$. Both strains are positive for hydrolysis of aesculin, tyrosine and urea, but negative for hydrolysis of adenine, casein, elastin, gelatin, guanine, testosterone and xanthine. Both strains are positive for utilization of cellobiose and L-rhamnose as carbon sources, but negative for utilization of adonitol, adipic acid, 2,3-butanediol, citrate, cellobiose, meso-erythritol, mhydroxybenzoate, 1,2-propanediol and raffinose as carbon sources. Both strains are positive for utilization of acetamide, L-alanine, Larginine, gelatin, proline, ornithine and serine as simultaneous sources of carbon and nitrogen. +, Positive; -, negative; w, weak utilization after 3 weeks.

\begin{tabular}{|lcc|}
\hline Characteristic & $\mathbf{1}$ & $\mathbf{2}$ \\
\hline Hydrolysis of: & & \\
Hypoxanthine & - & + \\
Utilization as sole sources of carbon and energy: & & \\
Acetate & - & + \\
iso-Amylalcohol & - & + \\
L-Arabinose & - & + \\
D-Galactose & - & W \\
D-Glucose & - & + \\
D-Gluconate & - & + \\
p-Hydroxybenzoate & W & - \\
myo-Inositol & - & + \\
L-Lactate & + & - \\
Lactose & + & - \\
Maltose & - & + \\
D-Mannitol & - & + \\
Melezitose & - & + \\
Sucrose & - & + \\
D-Sorbitol & + & - \\
Trehalose & - & + \\
D-Xylose & - & + \\
& & \\
\hline
\end{tabular}

27-37 ${ }^{\circ} \mathrm{C}$, but not at $42{ }^{\circ} \mathrm{C}$. Diffusible pigments are not produced. Melanoid pigment is not produced on ISP medium 6 or ISP medium 7. Hydrolyses aesculin, tyrosine and urea, but not adenine, casein, elastin, gelatin, guanine, hypoxanthine, testosterone or xanthine. Assimilates cellobiose, L-lactate, lactose, L-rhamnose and D-sorbitol as carbon sources, but not acetate, adonitol, adipate, isoamylalcohol, L-arabinose, 2,3-butanediol, citrate, mesoerythritol, D-galactose, D-gluconate, glucose, $m$-hydroxybenzoate, $p$-hydroxybenzoate, myo-inositol, maltose, Dmannitol, melezitose, 1,2-propanediol, raffinose, sucrose, trehalose or D-xylose. Utilizes acetamide, L-alanine, arginine, gelatin, proline, ornithine and serine as simultaneous carbon and nitrogen sources. Whole-organism hydrolysates contain meso-diaminopimelic acid and madurose as characteristic sugar. The major phospholipids are diphosphatidylglycerol, phosphatidylglycerol, phosphatidylinositol and phosphatidylinositol mannoside. The major menaquinone is $\mathrm{MK}-9\left(\mathrm{H}_{6}\right)$. The major fatty acids are $\mathrm{C}_{16: 0}$, iso- $\mathrm{C}_{16: 0}, \mathrm{C}_{18: 0}, \mathrm{C}_{18: 1} \omega 9 c$ and 10 -methyl- $\mathrm{C}_{18: 0}$.
The type strain is IMMIB L-889 ${ }^{\mathrm{T}}\left(=\mathrm{DSM} 45233^{\mathrm{T}}=\mathrm{CCUG}\right.$ $56587^{\mathrm{T}}$ ), which was isolated from the sputum of a 64 -yearold man suspected to be infected with Mycobacterium tuberculosis.

\section{Acknowledgements}

We thank Professor Dr Hans Georg Trüper for nomenclatural advice and Bettina Sträubler for excellent technical assistance.

\section{References}

Ara, I., Matsumoto, A., Bakir, M. A., Kudo, T., Omura, S. \& Takahashi, Y. (2008). Actinomadura bangladeshensis sp. nov. and Actinomadura chokoriensis sp. nov. Int J Syst Evol Microbiol 58, 1653-1659.

Bär, W., Wakili, J., Márquez de Bär, G., Steinhauer, H. \& Schweisfurth, H. (2003). Ungewöhnliche grampositive Stäbchenbakterien als Auslöser von Pneumonien. Pneumologie 57, 259-267 (in German).

Becker, B., Lechevalier, M. P., Gordon, R. E. \& Lechevalier, H. A. (1964). Rapid differentiation between Nocardia and Streptomyces by paper chromatography of whole-cell hydrolysates. Appl Microbiol 12, 421-423.

Cashion, P., Holder-Franklin, M. A., McCully, J. \& Franklin, M. (1977). A rapid method for base ratio determination of bacterial DNA. Anal Biochem 81, 461-466.

Chormonova, N. T. \& Preobrazhenskaya, T. P. (1981). Occurrence of Actinomadura in Kazakhstan soils. Antibiotiki 26, 341-345 (in Russian).

Collins, M. D., Pirouz, T., Goodfellow, M. \& Minnikin, D. E. (1977). Distribution of menaquinones in actinomycetes and corynebacteria. J Gen Microbiol 100, 221-230.

Couch, J. N. (1963). Some new genera and species of the Actinoplanaceae. J Elisha Mitchell Sci Soc 79, 53-70.

De Ley, J., Cattoir, H. \& Reynaerts, A. (1970). The quantitative measurement of DNA hybridization from renaturation rates. Eur $J$ Biochem 12, 133-142.

Felsenstein, J. (1981). Evolutionary trees from DNA sequences: a maximum likelihood approach. J Mol Evol 17, 368-376.

Felsenstein, J. (1985). Confidence limits on phylogenies: an approach using the bootstrap. Evolution 39, 783-791.

Fitch, W. M. (1971). Toward defining the course of evolution: minimum change for a specific tree topology. Syst Zool 20, 406-416.

Gordon, R. E. (1966). Some criteria for the recognition of Nocardia madurae (Vincent) Blanchard. J Gen Microbiol 45, 355-364.

Gordon, R. E. (1967). The taxonomy of soil bacteria. In The Ecology of Soil Bacteria, pp. 293-321. Edited by T. R. G. Gray \& B. Parkinson. Liverpool: University Press.

Gordon, R. E. \& Mihm, J. M. (1957). A comparative study of some strains received as nocardiae. J Bacteriol 73, 15-27.

Hanafy, A., Ito, J., lida, S., Kang, Y., Kogure, T., Yazawa, K., Yaguchi, T. \& Mikami, Y. (2006). Majority of Actinomadura clinical isolates from sputa or bronchoalveolar lavage fluid in Japan belongs to the cluster of Actinomadura cremea and Actinomadura nitritigenes, and the description of Actinomadura chibensis sp. nov. Mycopathologia 162, 281-287.

Henssen, A. (1957). Beiträge zur Morphologie und Systematik der thermophilen Actinomyceten. Arch Mikrobiol 26, 373-414.

Huß, V. A. R., Festl, H. \& Schleifer, K. H. (1983). Studies on the spectrophotometric determination of DNA hybridization from renaturation rates. Syst Appl Microbiol 4, 184-192. 
linuma, S., Yokota, A., Hasegawa, T. \& Kanamaru, T. (1994). Actinocorallia gen. nov., a new genus of the order Actinomycetales. Int J Syst Bacteriol 44, 230-234.

Jukes, T. H. \& Cantor, C. R. (1969). Evolution of protein molecules. In Mammalian Protein Metabolism, vol. 3, pp. 21-132. Edited by H. N. Munro. New York: Academic Press.

Kroppenstedt, R. M. \& Goodfellow, M. (1991). The family Thermomonosporaceae. In The Prokaryotes, 2nd edn, pp. 1085-1114. Edited by A. Balows, H. G. Trüper, M. Dworkin, W. Harder \& K. H. Schleifer. New York: Springer-Verlag.

Lechevalier, M. P. (1968). Identification of aerobic actinomycetes of clinical importance. J Lab Clin Med 71, 934-944.

Lechevalier, H. A. \& Lechevalier, M. P. (1968). A critical evaluation of the genera of aerobic actinomycetes. In The Actinomycetales, pp. 393405. Edited by H. Prauser. Jena: VEB Gustav Fischer Verlag.

Lechevalier, M. P. \& Lechevalier, H. A. (1970). Chemical composition as a criterion in the classification of aerobic actinomycetes. Int J Syst Bacteriol 20, 435-443.

Lechevalier, M. P., De Bièvre, C. \& Lechevalier, H. A. (1977). Chemotaxonomy of aerobic actinomycetes: phospholipid composition. Biochem Syst Ecol 5, 249-260.

Lu, Z., Wang, L., Zhang, Y., Shi, Y., Liu, Z., Quintana, E. T. \& Goodfellow, M. (2003). Actinomadura catellatispora sp. nov. and Actinomadura glauciflava sp. nov., from a sewage ditch and soil in southern China. Int J Syst Evol Microbiol 53, 137-142.

Ludwig, W., Strunk, O., Westram, R., Richter, L., Meier, H., Yadhukumar, Buchner, A., Lai, T., Steppi, S. \& other authors (2004). ARB: a software environment for sequence data. Nucleic Acids Res 32, 1363-1371.

Master, R. N. (1994). Mycobacteriology. In Clinical Microbiology Procedures Handbook. Edited by H. D. Isenberg. Washington, DC: American Society for Microbiology.

McNeil, M. M. \& Brown, J. M. (1994). The medically important aerobic actinomycetes: epidemiology and microbiology. Clin Microbiol Rev 7, 357-417.

McNeil, M. M., Brown, J. M., Jarvis, W. R. \& Ajello, L. (1990), Comparison of species distribution and antimicrobial susceptibility of aerobic actinomycetes from clinical specimens. Rev Infect Dis 12, 778-783.

Minnikin, D. E., Hutchinson, I. G., Caldicott, A. B. \& Goodfellow, M. (1980). Thin-layer chromatography of methanolysates of mycolic acid-containing bacteria. J Chromatogr A 188, 221-223.

Quintana, E. T., Trujillo, M. E. \& Goodfellow, M. (2003). Actinomadura mexicana sp. nov. and Actinomadura meyerii sp. nov., two novel soil sporoactinomycetes. Syst Appl Microbiol 26, 511-517.
Rainey, F. A., Ward-Rainey, N., Kroppenstedt, R. M. \& Stackebrandt, E. (1996). The genus Nocardiopsis represents a phylogenetically coherent taxon and a distinct actinomycete lineage: proposal of Nocardiopsaceae fam. nov. Int J Syst Bacteriol 46, 1088-1092.

Saitou, N. \& Nei, M. (1987). The neighbor-joining method: a new method for reconstructing phylogenetic trees. Mol Biol Evol 4, 406425.

Shirling, E. B. \& Gottlieb, D. (1966). Methods for characterization of Streptomyces species. Int J Syst Bacteriol 16, 313-340.

Stackebrandt, E., Rainey, F. A. \& Ward-Rainey, N. L. (1997). Proposal for a new hierarchic classification system, Actinobacteria classis nov. Int J Syst Bacteriol 47, 479-491.

Trujillo, M. E. \& Goodfellow, M. (1997). Polyphasic taxonomic study of clinically significant actinomadurae including the description of Actinomadura latina sp. nov. Zentralbl Bakteriol 285, 212-233.

Trujillo, M. E. \& Goodfellow, M. (2003). Numerical phenetic classification of clinically significant aerobic sporoactinomycetes and related organisms. Antonie Van Leeuwenhoek 84, 39-68.

Wayne, L. G., Brenner, D. J., Colwell, R. R., Grimont, P. A. D., Kandler, O., Krichevsky, M. I., Moore, L. H., Moore, W. E. C., Murray, R. G. E. \& other authors (1987). International Committee on Systematic Bacteriology. Report of the ad hoc committee on reconciliation of approaches to bacterial systematics. Int J Syst Bacteriol 37, 463-464.

Yassin, A. F. \& Hupfer, H. (2006). Williamsia deligens sp. nov., isolated from human blood. Int J Syst Evol Microbiol 56, 193-197.

Yassin, A. F., Haggenel, B., Budzikiewicz, H. \& Schaal, K. P. (1993). Fatty acid and polar lipid composition of the genus Amycolatopsis: application of fast atom bombardment-mass spectrometry to structure analysis of underivatized phospholipids. Int J Syst Bacteriol 43, 414-420.

Yassin, A. F., Rainey, F. A., Brzezinka, H., Burghardt, J., Lee, H. L. \& Schaal, K. P. (1995). Tsukamurella inchonensis sp. nov. Int J Syst Bacteriol 45, 522-527.

Yassin, A. F., Chen, W.-M., Hupfer, H., Siering, C., Kroppenstedt, R. M., Arun, A. B., Lai, W.-A., Shen, F.-T., Rekha, P. D. \& Young, C. C. (2007). Lysobacter defluvii sp. nov., isolated from municipal solid waste. Int $J$ Syst Evol Microbiol 57, 1131-1136.

Zhang, Z., Wang, Y. \& Ruan, J. (1998). Reclassification of Thermomonospora and Microtetraspora. Int J Syst Bacteriol 48, 411-422.

Zhang, Z., Kudo, T., Nakajima, Y. \& Wang, Y. (2001). Clarification of the relationship between the members of the family Thermomonosporaceae on the basis of 16S rDNA, 16S-23S rRNA internal transcribed spacer and $23 \mathrm{~S}$ rDNA sequences and chemotaxonomic analyses. Int J Syst Evol Microbiol 51, 373-383. 